\title{
Sustainability and Depletion Accounting for Non-Renewable Resources: The Case of Copper in Chile
}

\author{
Barry D. Green ${ }^{1} \&$ Keith A. Blatner ${ }^{1}$ \\ ${ }^{1}$ School of the Environment, Washington State University, Pullman, WA 99164-2812, USA \\ Correspondence: Keith A. Blatner, School of the Environment, Washington State University, Pullman, WA \\ 99164-2812, USA. Email: blatner@wsu.edu
}

\author{
Received: September 10, 2015 Accepted: September 28, 2015 Online Published: October 1, 2015 \\ doi:10.5539/enrr.v5n4p16 \\ URL: http://dx.doi.org/10.5539/enrr.v5n4p16
}

\begin{abstract}
This research develops a framework for assessing just compensation values for mining projects, where they might contribute toward a responsible, profitable, and sustainable path to economic growth and development. More specifically, it deals with methods to determine a "sustainable" rate of mineral extraction, putting a dollar value on the environmental impacts from various levels of mineral extraction. The project focuses on an emerging political economy (Chile) and uses an interdisciplinary approach. The approach rests on the assumption that the policy objectives of environmental protection and sustainable economic development can be subsumed into the "Hartwick rule" goal of investing mining rents in natural, social, and infrastructure capital. This study aids in policy decisions relating to benefit transfer to local/regional infrastructure investment.
\end{abstract}

Keywords: sustainable development, environmental compliance, analysis of environmental monitoring/remediation

\section{Introduction}

This paper concerns the paradoxical task of assuring sustainability, while exploiting the non-renewable mineral assets of a region. In practice and theory, mineral development triggers two concerns. In theoretical terms, the first concern is over the external effects of mineral exploitation, the second over the ideal rate of extraction of a non-renewable resource. In practical terms, the first concern focuses on the environmental and health effects of mining operations, while the second is concerned with generating sustainable economic benefits from the use of the mineral. From a social perspective, the revenues derived from extracting a resource should be sufficient to cover the full social costs of extraction - that is the external costs usually dominated by environmental and health effects, as well as the extraction costs themselves. After accounting for the full costs, the remaining revenues, the "resource rent" should be sufficient to justify extracting the metal now, as opposed to leaving it in the ground for future use. More specifically, the rate at which the mineral is extracted should generate a rent that balances current and future use of the asset.

\section{Background Literature}

Sustainability has been called "one of the least meaningful and most overused words in the English language" (Thiele, 2013). This necessitates the need when using the term "sustainability" to be concise and clear. The Organization for Economic Co-operation and Development (OECD, 2004) has taken the lead and the stance that sustainable development stands on three pillars, economic, social, and environmental. This position is well supported in more recent literature (e.g.: Schneider et al. (2011).

In OECD's convention of 1960 it stated "to achieve the highest sustainable economic growth and employment and a rising standard of living in member countries, while maintaining financial stability, and thus to contribute to the development of the world economy." (OECD, 2004) Due to the early stance of the third pillar (environmental) was not addressed until 1970 by the Secretary-General Emil Van Lennep, who then established the Environmental Directorate and the very first intergovernmental committee dealing with the environment. It should be noted that this stance towards sustainable development was well ahead of the Brundtland Report. But, even as the third pillar of environmental was being discussed, OECD was well aware of the fact that decision makers would need a clear framework to aid in implementation of all of the pillars economic, social and environmental policies, otherwise the whole exercise on sustainable development would be of little value (OECD, 2004). 
In 1987 World Commission on Environment and Development published "Our Common Future" (commonly referred to as the Brundtland report) (WCED, 1987). This report ushered in the generally accepted concept of sustainable development. To this end their definition has become the most widely used since its inception. The Brundtland report defined sustainable development as "development which meets the needs of current generations without compromising the ability of future generations to meet their own needs" (United Nations Economic Commission for Europe, 2015).

Mining received a separate section (Part IV) pertaining to sustainability at the World Summit on Sustainable Development, held in Johannesburg in 2002. Part IV describes mining's role in sustainable development in addition to other concerns such as mine life cycles, exploration and closure (Dashwood, 2012).

After the initial Brundtland Report was issued the focus of sustainability began to take center stage. One of the organizations that developed recommendations with the goal of sustainability was the OECD. Their recommendations towards sustainable development shows the interrelation between the use of natural resources, the environment and offers suggestions for addressing sustainable development by the incorporation of economic tools, and additional public participation.

We define a "sustainable rate of extraction" of a mineral as the rate of extraction that fulfills these tasks - covering both explicit extraction costs and external health and environmental costs as well as generating revenue that "appropriately" balances current and future economic requirements. In this study, we address two issues; first we test the feasibility of reducing a national methodology that addresses sustained growth in a mineral-exporting country on a national level, to a regional (in-country) method, and second, we propose methods for operationalizing practical and general procedures for sustainability accounting of mineral extraction along the lines of this definition (Auty \& Mikesell, 1998).

While our definition of sustainability is not new, it accords well with standard economic concepts. It is also consistent with several widely used definitions of sustainability. In particular, it implements Auty and Miksell's criterion for the use of sustainable use of minerals:

"The concept of sustainable development requires that the contribution to economic development be maintained, both during periods of temporary reduction in mineral exports and over the long run when mineral producing capacity declines relative to the size of the overall economy. What is required is not the sustainability of the mineral production that initially generates growth, but the maintenance of economic and social conditions for sustaining that growth." (Auty \& Mikesell, 1998:3)

"Extractive industries can contribute significantly to a country's economic development and often offer the first opportunities for foreign investment and private sector development. However, they can also aggravate or cause serious environmental, health, and social problems, including conflict and war" (Liebenthal et al., 2005:1). Several theoretical, philosophical, and operational problems must be addressed to measure sustainable development. First, the external health and environmental costs are notoriously difficult to measure. A major difficulty in both health and environmental cost measurement is impact uncertainty over time. Many environmental and health impacts of mining only become clear years and decades after extraction, perhaps when the mine has long since been shut down. Moreover, the value (price) of both health and environmental effects can be extremely hard to estimate. In particular, the price of a human life and the irreversible degradation of an environment or extinction of a species are considered to be untraceable "sacred" values by some. Even so, economists have developed price estimation methods. However, these methods tend to be expensive, situation dependent, and controversial.

The second major problem concerns the balance between current and future use in defining the sustainable rate of extraction for a non-renewable resource. A non-renewable resource is differentiated from a renewable resource in the fact that it exists on earth in a finite and exhaustible amount. Examples of this would include copper, gold, and oil. In contrast, a renewable resource such as trees may be harvested, as they will regrow over time if properly managed. With non-renewable resources being finite, extraction rates (use), are given more consideration during planning and operational phases. Unfortunately, renewable resources can ultimately become finite by being overused, and consequently, irreversibly depleted (Lesser et al., 1997). In terms of non-renewable resources there are two strands in current literature, one more theoretical; one more practical. The practical strand concentrates on measuring depletion in value terms in order to, for example, assess whether a country is saving or "dis-investing" in its mineral resources.

The theoretical strand stems from the "Hotelling model" for "optimal" (efficient) resource depletion of a non-renewable resource. The Hotelling model specifies a dynamically efficient rate of consumption (depletion) of a non-renewable resource by treating the mineral as an asset. In searching for an operational, sustainability-based criterion for mineral extraction, the Hotelling approach provides an important starting place. 
In the current international climate, environmental effects can attract considerable attention. In industrialized countries, regulations generally require mining concerns to mitigate, remediate/reclaim, or prevent any potential environmental harm. In emerging economies, regulations are quite variable, country dependent, and national needs for a clean environment compete with infrastructure and health needs more so than in industrialized countries.

Although, international mining standards are in place through the International Finance Corporation, and World Bank Environment, enforcement of the standards remain problematic (International Finance Corporation, 2006, and World Bank Environment, 1995). "Countries world-wide share concerns about ways in which to monitor the environmental behavior of multi-national companies. Questions exist concerning the capacity of countries to enforce, minimum standards to follow, companies setting their own standards, availability of data, and international cooperation" (Gerardu \& Wasserman, 1998:501). In these circumstances it may be useful to look at the overall assets of the mining enterprise to explore how the financial, technical and capital assets of the mining concern might best contribute to a host country's goals.

Governmental agencies in developing countries, be it economic development, environmental, or health related, are at a disadvantage when dealing with companies from the mining industry in terms of calculating long-term compensation for the extraction of their natural resources, and their resulting long-term environmental effects. With budget constraints, limited manpower, and possibly limited technical expertise, a need arises for a methodology to estimate in a "desktop review manner," calculations to determine compensation for the resources being mined, and the subsequent compensation requirements for the environmental degradation of the area, for both the short and long-term. This method fits in well with the recent international push for transparency by the Extractive Industries Transparency Initiative (EITI) 2015.

Various methods of measuring and accounting for resource depletion have examined financial compensation for the use of non-renewable resources on a multi-national or national basis (Auty \& Mikesell, 1998, Kellenberg, 1996). The concern is whether these methods adequately address compensation when considering environmental consequences brought about by mining of a non-renewable resource. A possible aid in answering this question is to examine resource depletion accounting methods on a smaller geographical scale for a particular mineral, and for baseline environmental damages. This paper will examine copper mining in Region III Chile through the use of three resource depletion methods, in an effort to determine the viability of the different models on a regional basis, and to explore whether they adequately address not only compensation for the use of the non-renewable resource, but baseline environmental concerns.

By addressing resource depletion accounting methods and including environmental damages, while using this "smaller/local" approach, a better determination can be made about the adequacy of financial compensation of non-renewable resources. The results will bring into discussion strength and weaknesses of the resource depletion accounting methods, and consideration of the market price of copper over the study timeframe, and whether or not it was adequate to address all associated costs.

This work has two basic premises. One concerns whether monetary values can be used in an accounting system that meaningfully determines the value of the current extraction of a resource versus the long run costs of that extraction. The second concerns viewing costs to include the necessity of assuring a sustainable society and environment. In terms of the accounting system, the question is whether there is a system of accounting of monetary calculations for the removal of a non-renewable resource that is practical, which can be reasonably used as a basis to estimate a dollar quantity which is available (surplus from operations), which could be injected into the economy to substitute for the removal of that non-renewable resource. Different schools of thought will be discussed concerning compensation for the removal of copper (resource depletion), and will be reflected in the methods of calculation.

Secondly, the need to protect the environment at some level is taken as an essential starting point. We assume that protection of the environment and protection of human health are fundamentally interrelated. As a practical matter, we employed information and models that are used for that purpose in the United States, because Chilean environmental laws are based on the framework of the U.S. Environmental Protection Agency.

\section{Study Area}

At the present time sustainable development studies have occurred, and are occurring in many transitional economies. One of these transitional economies is Chile, a country that has been diversifying its economy in recent years but is still mining dependent. Since Chile has a long history of dependence on mining, the problem of dependence on a non-renewable resource has been apparent for a period of years. In Region III, Chilean mining accounted for between 38.4 to 46.1 percent of the regional GDP between the years of 1996 and 2003. Several studies examine the role of mining and its current and potential relationship to sustainable development. A recent 
United Nations/United Nations Environmental Programme (UN/UNEP) (2003) study in Chile (Implementation of Policy Response Packages to Promote Sustainable Management of Natural Resources - Confronting Sustainability in the Mining Sector Role for a Sustainability Fund) examines mining and sustainability based upon two premises. One premise being that production is based on a finite resource, at least on a local scale, and the other stating that there is normally a strong degree of interdependence between mining exploitation and the local or regional community.

Figure 1 shows the geographic location of Region III (Atacama Region), within Chile. The regional capital is Copiapo, which is located near the coast and is home to slightly more than $60 \%$ or the region's population. Other cities in the region include Chanaral, a seaport, and Vallenar, a center for the mining industry (Atacama Region, 2015).

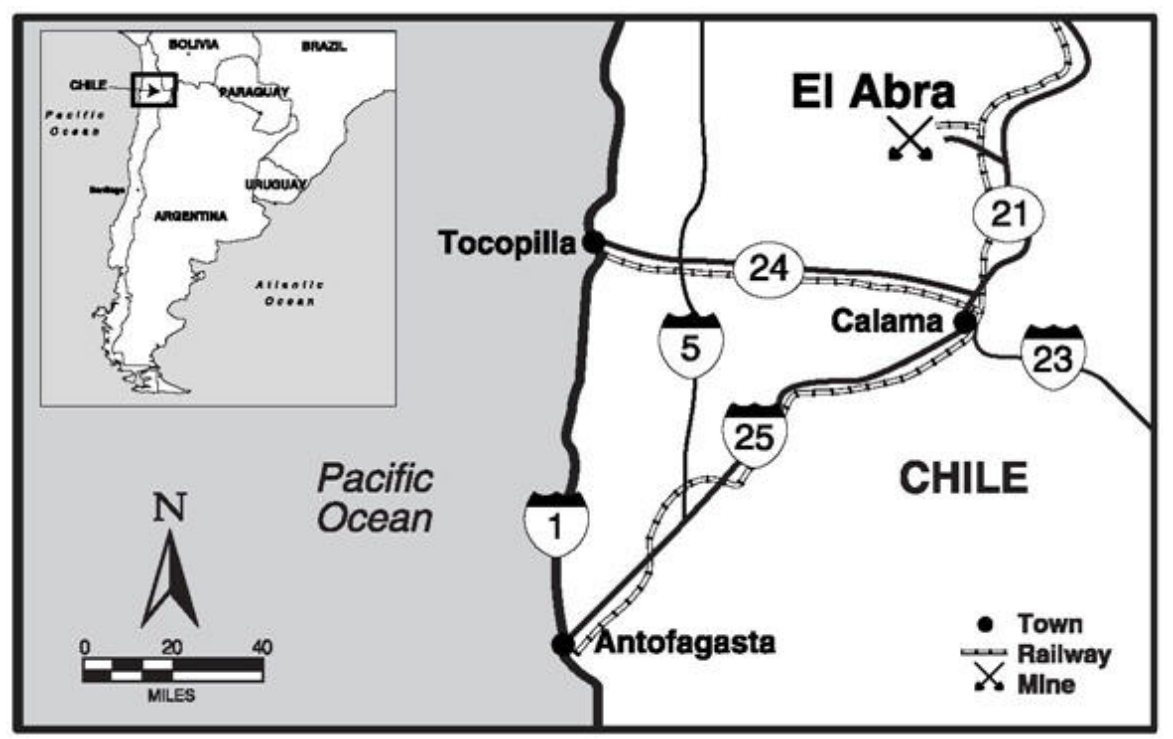

Figure 1. Region III (Atacama Region) Chile

The Atacama Desert, of which Region III is comprised, is an eco-region that is bordered to the north by the Sechura Desert eco-region of Peru, and the Matorral eco-region of Chile to the south, and the Andes Mountains to the east. Altitude for the Atacama Desert ranges between 9,842 and 16,404 ft. Temperature extremes are an average daytime high of $75.9\left({ }^{\circ} \mathrm{F}\right)$ in December, to an average low of $30.4\left({ }^{\circ} \mathrm{F}\right)$ in July. The Atacama is the driest place on earth with an annual precipitation of 1 millimeter (Altius Directory, 2015).

Region III in Chile is a region that is on an upward economic cycle, due to either direct employment in the mining industry, or being involved peripherally through a supporting business. Whereas, the economy in this region is also supported by other sectors of the economy such as agriculture, fishing, manufacturing, construction, and to lesser extent service industries, mining normally accounts for roughly 40 percent of the Region's economic activity. With this type of economy, and level of education, we found sufficient data/input address the necessary calculations for economic sustainability.

As mentioned Region III's main thrust in the economy is mining. The Chilean national mining system has companies, national and international, structured by a size classification for ongoing mining activity. The existing structure has large scale mining operations designated as category "A" operations. During the time period of 2001 -2005 , Category "A" concerns produced from 90 to 94 percent of the country's total copper output. Category "B" or medium size mining operations have accounted for 5 to 9 percent of Chile's copper output during the same time period, and the small or category " $\mathrm{C}$ " mines have produced the remaining amount of copper during this time (SERNAGEOMIN). A breakdown of the size of mining activities, types of operations, production and costs for copper producers to illustrate the current activity in Chile's Region III is provided in Table 1. 
Table 1. Active Copper Mining Facilities in Region III, Chile (2005)

\begin{tabular}{|c|c|c|}
\hline Category “A”(Company) & Mine Type & Total \# of Mines/ Projects/Plants \\
\hline CODELCO - El Salvador & Underground & 1 \\
\hline C. C. M. Candelaria & Open Pit & 1 \\
\hline CEMIN Ltda. & Open Pit & 1 \\
\hline CODELCO - El Salvador & Open Pit & 1 \\
\hline CODELCO - El Salvador & Plant - Heap Leaching & 1 \\
\hline CODELCO - El Salvador & Plant - Concentrator & 1 \\
\hline CODELCO - El Salvador & Plant - Smelter & 1 \\
\hline CODELCO - El Salvador & Plant - Refining & 1 \\
\hline C. C. M. Candelaria & Plant - Shipping (port) & 1 \\
\hline C. C. M. Candelaria & Plant - Concentrator & 1 \\
\hline Empresa Nacional de Mineria & Plant - Smelter & 1 \\
\hline Empresa Nacional de Mineria & Plant - Smelter & 1 \\
\hline Category “B” (Company) & Mine Type & Total \# of Mines/ Projects/Plants \\
\hline Mra. COBREX Ltda. & Underground & 1 \\
\hline Sociedad Punta del Cobre SA & Underground & 3 \\
\hline S. C. M. Carola & Underground & 1 \\
\hline C. M. Maricunga & Open Pit & 1 \\
\hline CEMIN Ltda. & Open Pit & 1 \\
\hline E. M. Mantos Blancos - MV & Open Pit & 1 \\
\hline Placer Dome - Latin America & Project & 1 \\
\hline E. M. Mantos Blancos - MV & Plant - Electric & 1 \\
\hline E. M. Mantos Blancos - MV & Plant - Electric & 1 \\
\hline Empresa de Nacional de Mineria & Plant - Heap Leaching & 1 \\
\hline Sociedad Punta del Cobre SA & Plant - Leaching & 1 \\
\hline Sociedad Punta del Cobre SA & Plant & 1 \\
\hline C. M. San Estaban 1a SA & Plant & 1 \\
\hline COEMIN Ltda. & Plant & 1 \\
\hline C. M. Maricunga & Plant - Smelter & 1 \\
\hline CEMIN Ltda. & Plant & 1 \\
\hline \multirow[t]{5}{*}{ Category "C" } & Mine Type & Total \# of Mines/ Projects/Plants \\
\hline & Underground & 147 \\
\hline & Open Pit & 4 \\
\hline & Projects & 2 \\
\hline & Plants & 8 \\
\hline
\end{tabular}

SOURCE: Sernageomin - Anuario de la Mineria de Chile, 2005.

\section{Models}

Resource depletion may be calculated in several different ways. Normally with resource depletion and sustainability, the calculations are made for the economy of a country, although here we will focus on one regionChile's Region III. Of the approaches to calculating resource depletion for the determination of a potential income stream to cover the protection of human health, with funds above that level to be invested in the non-mining 
economy, the following three methods were used. It is not our intent to ascertain the "best" or "more correct" method, but to provide a contribution that may be used in future comparison of these models at a smaller sub multi-national or national basis.

\subsection{World Bank Method}

The World Bank method does not consider new discoveries that are added to national/regional reserves. In addition, to the resource depletion value calculated the World Bank Method assigns an environmental damage of $\$ 20$ (US)/metric ton of $\mathrm{CO}_{2}$ to the emitting country/region (Neumayer, 2000).

$$
(\mathrm{P}-\mathrm{AC}) \cdot \mathrm{R}
$$

$\mathrm{P}=$ resource price

$\mathrm{AC}=$ average cost

$\mathrm{R}=$ depletion

\subsection{Net Price Approach (Repetto)}

The Hotelling's rule states; "The mineral rights price, which is the difference between the mineral price and the sum of extraction and finding cost, rises at the rate of interest (Lesser et al. 1997: 476 - 477)." The net price approach is similar to Hotelling's rule, except that resource rent or net price is defined as the current market price minus average extraction costs, including a normal profit on the capital investment. Resource depletion is the net reduction in the stock of the natural resource times the net price (Neumayer, 2000).

$$
(\mathrm{P}-\mathrm{AC}) \cdot(\mathrm{R}-\mathrm{D})
$$

$\mathrm{D}=$ resource discoveries

Normally, the World Bank and the Net Price (Repetto) methods will account for a wider and higher range of estimates due to the adjustment of GDP.

\subsection{User Cost (El Serafy - United Nations) Method}

This method rejects Hotelling, and Rapetto and divides the net receipts from mineral extraction into capital consumption representing the amount earned at the expense of eroding the value of the asset, and net receipts available for consumption. The latter represents true income and is based on the Hicksian notion that true income is a level of consumption that can be sustained indefinitely. The attractiveness of this method is twofold in that it is the accepted method to calculate resource depletion used by the United Nations, and it conforms with the conventional definition of sustainable income by requiring that the natural capital asset be replaced only to the extent needed to maintain the income stream indefinitely (Auty and Mikesell, 1998). This method usually provides a more narrow range and lower estimates due to less severe adjustments in the GDP.

$$
(\mathrm{P}-\mathrm{AC}) \cdot \mathrm{R} \cdot\left[\frac{1}{(1+r) n+1}\right]
$$

$\mathrm{P}=$ resource price

$\mathrm{AC}=$ average cost

$\mathrm{R}=$ depletion

$\mathrm{r}=$ discount rate

$\mathrm{n}=$ is the number of remaining years of the resource stock if production was the same in the future as in the base year (Neumayer, 2000).

\subsection{Use of Resource Strategies Incorporates EPA Model for Generation of Environmental Compensation}

The World Bank method, in conjunction with the Net Price method and the User Cost method all display varying ways of calculating resource depletion, but environmental quality also has to be given consideration. Previous calculations have been conducted at a national level and either included some form of environmental remediation in their calculations, a generic figure such as US dollars/per ton CO2/person, or did not address environmental degradation. Whereas a paucity of environmental models exist to deal with the mining industry, and more specifically the copper industry, Resource Strategies Incorporated (RSI), a specialist in world mining and metals production, (under a contract with the United States Bureau of Mines, Branch of Procurement) developed a model to assign economic impacts to the managing of copper mines and their associated waste, non-hazardous 
(EPA Subtitle D) and hazardous (EPA Subtitle C). This model assigned four different levels of active and long-term monitoring for various environmental indicators under the framework of EPA regulations, in addition to a scenario for abandonment. The scenarios include:

\subsubsection{Scenario One}

Groundwater monitoring and permitting are required for existing waste units, but no major change from current waste management practices would be expected. This program is less stringent than the current Subtitle D program. For example, it does not require run-on/run-off controls, calls for a less sophisticated closure cover, and requires a shorter post-closure period and a less stringent groundwater monitoring configuration. It represents the lower boundary, in terms of compliance cost, that is likely under a "minimal" regulatory approach.

\subsubsection{Scenario Two}

Stringent groundwater monitoring, run-on/run-off controls, a vegetative cover over waste dumps and post-closure cover maintenance would be required. This scenario more closely resembles the current subtitle D program. However, it has been modified in order to calculate compliance costs. For example, Scenario No. 2 does not consider location standards or performance goals on a case by case basis when estimating the cost of compliance.

\subsubsection{Scenario Three}

This scenario requires closure of all existing waste management units and construction of new units. Single synthetic liner systems would be mandated. Existing units would be closed with the waste in place and covered with a synthetic cap. This represents a less stringent version of the current Subtitle C program. For example, it allows for a less sophisticated liner system and groundwater monitoring configuration. This scenario was developed to provide an estimate of the cost of compliance under a less rigorous Subtitle C regulatory approach.

\subsubsection{Scenario Four}

This scenario represents a Subtitle $\mathrm{C}$ approach to the regulation of mining wastes. It is the most stringent and most costly of the four scenarios in that it assumes double liner systems with leachate detection and collection and more elaborate capping of closed units is required.

\subsubsection{Abandonment}

Implementation of abandonment is a common criterion under Subtitle D for landfill waste units. On the basis of this legislative precedence, the inclusion of abandonment as a feasible option under Scenarios 3 and 4 was analyzed for copper beneficiation and processing waste units (RSI, 1990).

There has been a movement by the governments of developing countries to adopt environmental regulatory frameworks from industrialized countries. This has proceeded to the point where the Chilean government's environmental protection framework is loosely modeled after the United States Environmental Protection Agency (EPA) (Warhusrt, 1994). Although, the use of an environmentally well-developed framework may be a first step, the implementation and enforcement portions of such a framework are not as easily transferrable. As put forth in the findings of the Environmental Performance Review on Chile by the Organization for Economic Co-operation and Development, it will be necessary for Chile to: "i) thoroughly and efficiently implement its environmental policies; ii) further integrate environmental concerns into economic, social and sectoral decisions; and iii) strengthen its international environmental co-operation" (OECD, 2005:2). So in time this may prove to be the way to proceed, but for now the comparisons are somewhat limited and enforcement of these environmental standards is unobtainable.

At the present time whatever method/approach ultimately proves to be the most efficient and effective (i.e., polluter pays), one has to start with a realistic baseline and proceed from that point. The baseline that we have chosen should be accepted without reservation is that of protecting human health in the mining project area. Without an accepted baseline the need to negotiate does not exist. One logical method for establishing this baseline, or starting point is the environmental regulations of the EPA due to their history and the parallel to Chile's environmental regulations.

\section{Data and Methods}

Data sources for the measureable components were initially identified during an extended visit to Chile in the fall of 2005. During this time meetings were conducted with governmental representatives from the Chilean national mining concern (CODELCO), the Chilean Copper Commission (Cochilco), the National Institute of Statistics (INE), the Ministry of Mines, the Central Bank of Chile (Banco Central de Chile), the National Business for Mining in Chile (ENAMI), the National Commission for the Environment (CONAMA - national and Region III), 
and the National Service for Geology and Mining (SERNAGEOMIN - national and Region III). In addition to this, meetings with faculty members from the University of Austral - Valdivia, Catholic University of Chile - Santiago, University of Chile - Santiago (Agriculture, and Mining campuses), and the University of Atacama - Copiapo, at their Technical Information Center were held. Additional information was obtained either by email or phone contact with the U.S. Environmental Protection Agency (EPA), the United States Geological Survey (USGS), Mine Cost Ltd., Western Mine Cost, and Phelps Dodge.

The data that was compiled for the calculations presented in Tables 2 and 3 were comprised of resource depletion data derived from specific mining company annual reports, Chilean mineral specific (copper) organization reports, and Chilean governmental agency production reports. Copper reserves were obtained from the Central Bank of Chile (Banco Central), the United States Geological Survey (USGS), and USGS sponsored research. Relevant economic data (GDP, GDP deflator, and consumption of fixed assets) was obtained from the Central Bank of Chile. Prices of copper commodities were obtained from past data on the London and New York Copper Exchanges, and operating costs were derived from information provided by World Mine Cost Data Exchange, Inc. Environmental data came from a Chilean environmental agency, Resource Strategies Incorporated, the U. S. Environmental Protection Agency (USEPA), and the United Nations.

Table 2. Total Calculations in Millions of 2000 US \$ - 1992 - 1998 unless otherwise denoted.

\begin{tabular}{|c|c|c|c|c|c|c|c|}
\hline & 1992 & 1993 & 1994 & 1995 & 1996 & 1997 & 1998 \\
\hline \#1 National GDP & 49221 & 52660 & 55666 & 61582 & 61249 & 65137 & 67084 \\
\hline \#1 Regional GDP & 841 & 930 & 1063 & 1213 & 1271 & 1353 & 1439 \\
\hline Percent of Region III of National GDP & 1.7 & 1.8 & 1.9 & 2.0 & 2.1 & 2.1 & 2.1 \\
\hline \#2 Consumption of Fixed Capital - National & 5316 & 5712 & 6157 & 6683 & 7298 & 7984 & 8706 \\
\hline \#3 Consumption of Fixed Capital Regional & 90 & 103 & 117 & 134 & 153 & 168 & 183 \\
\hline \#4 Product Price US \$/metric ton & 2802 & 2284 & 2688 & 3317 & 2513 & 2442 & 1746 \\
\hline \#5 Ave. Product Cost US \$/met ton & 2240 & 2192 & 1839 & 1314 & 1444 & 1443 & 1365 \\
\hline \#6 RESERVES COMBINED NATIONAL\#s million metric tons & 78.0 & 80.0 & 104.0 & 134.0 & 161.5 & 163.0 & 164.5 \\
\hline \#7 Region III reserves \#s in million metric tons & 6.6 & 6.0 & 8.5 & 16.9 & 18.7 & 18.3 & 19.4 \\
\hline \#8 PRODUCTION National (million met tons fine) & 1.9 & 2.1 & 2.2 & 2.5 & 3.1 & 3.4 & 3.7 \\
\hline \#8 PRODUCTION Region III (million met tons fine) & 0.16 & 0.15 & 0.18 & 0.31 & 0.36 & 0.38 & 0.43 \\
\hline Region III \% of national & $8.5 \%$ & $7.5 \%$ & $8.2 \%$ & $12.6 \%$ & $11.6 \%$ & $11.2 \%$ & $11.8 \%$ \\
\hline World Bank Resource Depletion Region III (millions 2000 US \$) & 92.2 & 14.2 & 155.2 & 629.7 & 385.2 & 378.2 & 165.1 \\
\hline $\begin{array}{l}\text { Change in Region III reserves from previous year- metric tons } \\
\text { (millions } 2000 \text { US \$) }\end{array}$ & -0.09 & 0.150 & 1.97 & 3.78 & 3.19 & 0.17 & 0.18 \\
\hline $\begin{array}{l}\text { Repetto (Net Price) Resource Depletion Region III (millions } 2000 \\
\text { US \$) }\end{array}$ & 140.0 & 0.4 & 1515 & 6941 & 3024 & 210.4 & 97.7 \\
\hline Years remaining of reserves at mining rate of current year & 40.4 & 38.9 & 46.7 & 53.7 & 52.0 & 48.2 & 44.8 \\
\hline El Serafy (User Cost) Resource Depletion (millions 2000 US \$) & 3.5 & 0.4 & 2.3 & 6.9 & 3.5 & 6.0 & 0.9 \\
\hline \#9 Carbon Dioxide emissions metric tons/capita & 2.603 & 2.599 & 2.949 & 3.112 & 3.507 & 3.975 & 3.887 \\
\hline \#10 Region III population for corresponding year & 235105 & 238456 & 241801 & 245155 & 248154 & 251171 & 254184 \\
\hline Carbon Dioxide Emissions@ 20 (constant) US \$/mt/capita & 12.3 & 12.4 & 14.3 & 15.3 & 17.4 & 20.0 & 19.8 \\
\hline \#11Region III \#1-Least Stringent (total) & 5.3 & 5.0 & 5.9 & 10.1 & 11.6 & 12.2 & 13.9 \\
\hline \#11 Region III \#1-Least Stringent (total) w/processing & & & & 10.2 & 11.7 & 12.3 & 14.1 \\
\hline \#11 Region III \#4 -Most Stringent w/abandonment (total) & 130.2 & 122.4 & 145.1 & 249.5 & 286.0 & 300.5 & 343.9 \\
\hline \#12 Region III mining profits (mil) & 50.6 & 24.8 & -12.0 & 399.1 & 174.9 & 274.3 & 105.0 \\
\hline
\end{tabular}


Table 3. Total Calculations in millions of Year 2000 US \$ 1999-2002 \& 2005 unless otherwise noted

\begin{tabular}{|c|c|c|c|c|c|}
\hline & 1999 & 2000 & 2001 & 2002 & 2005 \\
\hline \#1 National GDP & 66814 & 69646 & 72024 & 73606 & 89840 \\
\hline \#1 Regional GDP & 1417 & 1391 & 1454 & 1397 & 1505 \\
\hline$\%$ of Region III of National GDP & 2.1 & 2 & 2 & 1.9 & 1.7 \\
\hline \#2 Consumption of Fixed Capital National & 9310 & 9848 & 10418 & $10533 *$ & $10884 *$ \\
\hline \#3 Consumption of Fixed Capital Regional & 196 & 197 & 208 & $210^{*}$ & $217^{*}$ \\
\hline \#4 Product Price US \$/metric ton (millions) & 1627 & 1814 & 1534 & 1491 & 3248 \\
\hline \#5 Ave. Product Cost US \$/metric ton (millions) & 1253 & 1231 & 1151 & 1183 & 1890 \\
\hline \#6 Reserves Combined metric tons (millions) & 162.0 & 161.0 & 160.0 & 160.0 & 360.0 \\
\hline \#7 Region III reserves (millions) & 16.7 & 14.3 & 14.4 & 14.4 & 29.2 \\
\hline \#8 Production National (million metric tons fine) & 4.4 & 4.6 & 4.7 & 4.6 & 5.3 \\
\hline \#8 Production Region III (million metric tons fine) & 0.5 & 0.4 & 0.4 & 0.4 & 0.4 \\
\hline Region III \% of national & $10.3 \%$ & $8.9 \%$ & $9.0 \%$ & $9.0 \%$ & $8.1 \%$ \\
\hline World Bank Resource Depletion Region III & 169.3 & 237.7 & 198.8 & 127.2 & 603.5 \\
\hline Change in Region III reserves from previous year- metric tons (millions) & -0.3 & -0.1 & -0.1 & 0.0 & 0.0 \\
\hline Repetto (Net Price) Resource Depletion Region III & 265.6 & 289.5 & 198.8 & 127.2 & 603.5 \\
\hline Years remaining of reserves at mining rate & 36.9 & 35.2 & 33.6 & 34.9 & 67.4 \\
\hline El Serafy (User Cost) Resource Depletion & 8.8 & 17.3 & 25.6 & 27.1 & 44.1 \\
\hline \#9 Carbon Dioxide emissions metric tons/capita & 4.2 & 3.9 & 3.5 & 3.6 & 4.1 \\
\hline \#10 Region III population for corresponding year & 257190 & 260190 & 262239 & 264264 & 270371 \\
\hline Carbon Dioxide Emissions US \$/mt/capita (millions of 2000 US \$) & 21.4 & 20.1 & 18.6 & 19.2 & 22.0 \\
\hline \#11Region III \#1-Least Stringent (total) & 14.5 & 13.1 & 13.8 & 13.3 & 13.9 \\
\hline \#11 Region III \#1-Least Stringent (total) w/processing & 14.7 & 13.2 & 13.9 & 13.4 & 14.1 \\
\hline \#11 Region III \#4 -Most Stringent w/abandonment (total) & 359.2 & 323.5 & 340.5 & 327.7 & 343.6 \\
\hline \#11 Region III \#4 -Most Stringent w/abandonment (total) w/processing & 362.4 & 326.9 & 344.2 & & \\
\hline \#12 Region III mining profits & 108.2 & 162.0 & 121.1 & 68.0 & 437.6 \\
\hline
\end{tabular}

\section{Sources for Tables \#2 and \#3}

\#1 Banco Central (Central Bank of Chile)

\#2 Central Bank of Chile-(includes housing, rest of construction, machinery \& equipment - 1996 \& depreciation)

\#3 Percentage based off of GDP

\#4 Refined B.M.L. London and COCHILCO

\#5 1992 and 1993-CODELCO costs, 94\% production, and applied to Region III from CODELCO and Candelaria. Remaining years used percentage production and applied to Region III from CODELCO, CODELCO-SX-EW, and Candelaria (weighted)

\#6 Combined projections from Banco Central and USGS

\#7 Region III reserves based off of percentage of Region III production

\#8 Annuario del Cobre, 1986-2005 COCHILCO

\#9 United Nations - Statistics Division

\#10 Instituto Nacional de Estadísticas "Chile Hacia el 2050"

\#11 Resource Strategies Incorporated

\#12 Known profits for between $53.9 \%$ - 75.7\%, average for remaining percentage 
Calculations were based on the formula presented in Auty and Mikesell (1997), Sustainable Development in Mineral Economics, but outcomes were determined for a particular region (Region III, Chile), rather than on a national level. This endeavor was undertaken to see if present resource depletion methodology put forth would satisfy "sustainable development" in the mining sector related to Region III Chile. We based our comparisons/conclusions off of the sustainable development definition put forth by Auty and Mikesell (1998:3) as previously noted.

In moving from a national to a regional calculation some tradeoffs had to be made. A large portion of Region III specific data exists for reserves, production, processing, GDP, GDP by sector, and this allowed for some Region III specific calculations. Other items such as product price, and consumption of fixed assets, discount rate, and exchange rates were calculated using national data, and then adjusting this data to a regional level.

After meetings with the Chilean National Commission for the Environment (CONAMA) and a review of their national and regional environmental data, it was decided to deal with the deterioration of environmental quality (DQR) by setting the damage initially at zero (starting at, 2005) and accounting for it in the future by the high environmental calculation (PR-1). We believe this is an acceptable approach due to the fact that mining has been ongoing in this area for more than a century, and to try and identify specific companies or projects responsible for historic environmental deterioration is all but impossible. Also, in the environmental damages (PR) category of calculations a credit for company specific environmental projects proved to be impossible, due to lack of site specific environmental expenditures. We feel that under any circumstance, the best approach when dealing with a company/agency or consortium on a mining project is to have the controlling interest provide their financial records showing environmental expenditures. Dependent upon negotiations, these expenditures can be subtracted from the high environmental calculations (PR-1) in conjunction with a long-term agreed upon accounting approach to environmental deductions. Tables 2 and 3 provide total calculations for the studied years.

\subsection{Terms and Derivation}

This study assumes health costs as non-negotiable social costs. They were viewed as part of the costs of mining, though in national accounts these are "externalities," and are not explicitly counted. Hence, health costs are met by direct payments from the rents to the resource. The position taken here is that, in principle health costs should be part of the "cost of business" and should be paid.

Likewise, environmental damages are externalities, which are not directly counted as costs in national accounts except to the extent environmental measures are required in the course of doing business. Here we take the perspective that compensation for environmental damages need not be some form of direct remediation of the damages. Compensation for environmental damages can range from literal return to the pre-existing state (rarely possible) to cash, in lieu, payments. We approach environmental compensation for Region III mining activities by assuming direct payment through the calculation of sustainable income, which is categorized as environmental domestic product (EDP). While mining company and agency information from Region III was used initially, any gaps in information were taken from the next higher level available (national, appropriate models) and adjusted to a regional basis and used accordingly.

The estimate of sustainable income (EDP) used was based upon data availability for each category, and by the three methods of resource depletion (RD) discussed previously. For the World Bank method there were two calculations, one including their built in environmental cost $\left(\mathrm{CO}_{2}\right)$, and the other without the built in environmental cost $\left(\mathrm{CO}_{2}\right)$. The figures derived from the resource depletion (RD) calculations were used in accordance with environmental and resource accounting (EARA) methods that recognize the specific contribution of natural resources to the national output, which is shown in GDP measurements (Table 1). In general, we focused on the World Bank, Net Price (Repetto), and User Cost (El Serafy - UN) measures. Two calculations for the restoration of environmental damage (PR) were also made. PR1 (high value) encompasses maximum ( $100 \%$ perceived or real) environmental protection/ remediation, and PR2 (low value) the minimum environmental expenditures to safeguard human health. The difference between the PR1 and PR2 values comprise the available capital to be reinvested in Region III, Chile.

\section{Results}

\subsection{World Bank}

The results indicate that even at the lower environmental level (EDP2 - protection of human health) there exists a shortfall between the level of sustainable income, and profits being shown by the mining industry on a regional level, as EDP2 plus regional profits does not equal the current regional GDP - at current international prices and industrial structure. Assuming this shortfall is real, there are no excess rents on which to build an opportunity for 
negotiations for using excess rent for greater environmental protection (EDP). Several unknown factors with this method are the current amount of taxes being paid by the regional mining companies and the revenue that could be redirected in lieu of these taxes and the amount of current spending by the mining companies on environmental protection. Finally this method does not account for the deterioration of environmental quality (DQR).

\subsection{World Bank plus $\mathrm{CO}_{2}$}

The advantage to the revised calculations lies in $\mathrm{CO}_{2}$ being used by the World Bank as a proxy for all pollutants, thus taking into consideration the overall deterioration of environmental quality (DQR). However, the results are very similar to previous World Bank calculations. Hence, there appears to be a shortfall in income based on current prices and market structure needed to achieve the lower level environmental protection (human health - EDP2).

\subsection{Net Price (Repetto)}

With the addition of being able to account for new resource discoveries this method is better suited for use in a smaller geographic region. For the years shown below, there is still a deficit when using profits in the calculations for EDP using PR2 and PR1. Using the full set of years (1992-2002, and 2005, Tables 4-7), it turns out there are several years where the GDP could be maintained well above the current yearly GDP level, which leaves open the possibility of working with a long-term averaging scenario. In addition, this does not take into account the current expenses being paid by mining concerns for taxes, and expenses for environmental remediation/reclamation, which could lead to a larger financial stream for analysis. But once again deterioration of environmental quality is not addressed.

Table 4. World Bank in Millions of Year 2000 US Dollars

\begin{tabular}{lrrrr}
\hline & 1992 & 1997 & \multicolumn{1}{c}{2002} & \multicolumn{1}{c}{2005} \\
\hline Regional GDP & 841.0 & 1353.0 & 1397.0 & 1505.0 \\
\#1 Consumption of Fixed Capital Regional & 90.0 & 168.0 & 210.0 & 217.0 \\
World Bank Res. Depletion Region III & 92.3 & 378.2 & 127.2 & 603.5 \\
Region III \#1-Least Stringent (total - 95-05 incl. processing) & 5.3 & 12.3 & 13.4 & 14.1 \\
EDP (using PR2) & 653.5 & 794.5 & 1046.5 & 670.4 \\
Region III \#4 -Most Stringent w/abandon (total-99-01 includes processing) & 130.3 & 300.5 & 327.7 & 343.6 \\
EDP (using PR1) & 528.5 & 506.3 & 732.1 & 340.9 \\
Region III mining profits & 50.6 & 274.3 & 68.0 & 437.6 \\
\hline
\end{tabular}

Table 5. World Bank Plus CO2 in Millions of Year 2000 US Dollars

\begin{tabular}{lrrrr}
\hline & 1992 & 1997 & \multicolumn{1}{c}{2002} & \multicolumn{1}{c}{2005} \\
\hline Regional GDP & 841.0 & 1353.0 & 1397.0 & 1505.0 \\
\#1 Consumption of Fixed Capital -Regional & 90.0 & 168.0 & 210.0 & 217.0 \\
World Bank Res. Depletion Region III & 92.3 & 378.2 & 127.2 & 603.5 \\
Region III \#1-Least Stringent (total - 95-05 incl. processing) & 5.3 & 12.3 & 13.4 & 14.1 \\
Carbon Dioxide Emissions @ 20 (constant) US \$/met ton/capita & 12.2 & 20.0 & 19.2 & 22.0 \\
EDP (using PR2) & 641.3 & 774.5 & 1027.2 & 648.4 \\
Region III \#4 -Most Stringent w/abandon (total-99-01 includes processing) & 130.2 & 300.5 & 327.7 & 343.5 \\
Carbon Dioxide Emissions @ 20 (constant) US \$/met ton/capita & 12.3 & 20.0 & 19.2 & 22.2 \\
EDP (using PR1) & 516.3 & 486.3 & 712.9 & 318.9 \\
Region III mining profits & 50.6 & 274.3 & 68.0 & 437.6 \\
\hline
\end{tabular}


Table 6. Net Price in Millions of Year 2000 US Dollars

\begin{tabular}{|c|c|c|c|c|}
\hline & 1992 & 1997 & 2002 & 2005 \\
\hline Regional GDP in & 841.0 & 1353.0 & 1397.0 & 1505.0 \\
\hline \#1 Consumption of Fixed Capital - Regional & 90.0 & 168.0 & 210.0 & 217.0 \\
\hline Repetto (Net Price) Resource Depletion Region III & 140.0 & 210.4 & 127.2 & 603.5 \\
\hline Region III \#1-Least Stringent (total - 95-05 incl. processing) & 5.3 & 12.3 & 13.4 & 14.1 \\
\hline EDP (using PR2) & 605.7 & 962.3 & 1046.5 & 670.4 \\
\hline $\begin{array}{l}\text { Region III \#4 -Most Stringent w/abandon (total- 99-01 includes } \\
\text { processing) }\end{array}$ & 130.3 & 300.5 & 327.7 & 343.6 \\
\hline EDP (using PR1) in US \$ & 480.8 & 674.1 & 732.1 & 340.9 \\
\hline \#12 Region III mining profits & 50.6 & 274.3 & 68.0 & 437.6 \\
\hline
\end{tabular}

Table 7. User Cost in Millions of Year 2000 US Dollars

\begin{tabular}{|c|c|c|c|c|}
\hline & 1992 & 1997 & 2002 & 2005 \\
\hline Regional GDP & 841.0 & 1353.0 & 1397.0 & 1505.0 \\
\hline \#1 Consumption of Fixed Capital -Regional & 90.0 & 168.0 & 210.0 & 217.0 \\
\hline El Serafy (User Cost) Resource Depletion & 3.5 & 6.0 & 27.1 & 44.1 \\
\hline Region III \#1-Least Stringent (total - 95-05 incl. processing) & 5.3 & 12.3 & 13.4 & 14.1 \\
\hline EDP (using PR2) & 742.2 & 1166.7 & 1146.5 & 1229.8 \\
\hline $\begin{array}{l}\text { Region III \#4 -Most Stringent w/abandon (total-99-01 includes } \\
\text { processing) }\end{array}$ & 130.3 & 300.5 & 327.7 & 343.6 \\
\hline EDP (using PR1) & 617.2 & 878.5 & 832.2 & 900.3 \\
\hline \#12 Region III mining profits & 50.6 & 274.3 & 68.0 & 437.6 \\
\hline
\end{tabular}

\subsection{User Cost (El Serafy)}

We now examine the fourth method for accounting for new resource discoveries, and with the additions of calculating the remaining life of the resource being mined and the income from resource receipts that should be considered as capital depreciation. The years 1997 and 2005 indicate the ability of mining concerns to meet the funding level of EDP2, while still possessing some resources for negotiation purposes. Once again a full set of years (1992-2002, and 2005) illustrates additional years where the GDP could be maintained above the current yearly GDP level, which leaves open the possibility of working with a long-term averaging scenario. In addition this does not take into account the current expenses being paid by mining concerns for taxes, and expenses paid out for environmental remediation/reclamation. But once again deterioration of environmental quality is not addressed.

\section{Conclusions}

The findings show the approach is realistic in that the measurement of environmental compensation on a unit cost basis at the protection of human health level can be assessed through the resource depletion calculations. These calculations, from a national to regional perspective, are a necessary step prior to attempting to refine this methodology further, logically a single mine-site. The relevancy of this can best be described by points one and two taken from the Office of Economic Co-operation and Development's (OECD) 2005 "Recommendations Towards Sustainable Development," shown below. This illustrates the direction and hopeful contribution of this work.

8.1 Develop economic analyses of environment-related policies, expanding both economic information on the environment (e.g. on environmental expenditure, environment-related taxes, health risk assessment, water and energy prices) and cost-benefit analysis of projects and legislation relating to the environment (8) 


\subsection{Review ways and means of integrating environmental concerns in fiscal instruments and policies (8)}

Ultimately, after more precise/accurate numbers have been gathered and analyzed it may be found that full economic compensation for resource depletion and its environmental effects are unrealistic. In a scenario of this nature the potential costs could run into the billions of dollars. However, it could also be shown that a greater percentage of environmental costs could be negated with a percentage of the rent between addressing the upper limit of environmental costs and the low end value of protecting human health, by reinvesting a percentage of the rent into the regional economy.

Whereas, this approach offers no guarantees, we believe that it was worthwhile to explore because of the following reasons:

- It provides a comprehensive approach to "sustainable" development.

- It provides a starting point for future dialogue.

- It is a realistic method to discuss sustainable development related to mining at a regional level.

- It estimates the amount of capital required to replace copper resource depletion at a regional level.

- It provides a framework for the allocation of resources, related to sustainable development.

- It provides a framework to protect human health.

- It provides the mining concern a transparent guideline of what is expected.

- It involves all decision making parties in the policy process (mining concerns, governments, and NGOs).

A final issue to ponder is "full cost pricing." This study has shown a shortfall of funds needed to achieve sustainable development at current prices. With funds unavailable in the current system for sustainable development, how can the system be adjusted to incorporate "wages of sustainability" (depletion, environment, and health)? We feel the User Cost (El Serafy) method provides a possible starting point to address this question in greater depth.

\section{References}

Altius Directory. (2015). Retrieved June 24, 2015, from http://www.altiusdirectory.com/Travel/atacama-desert.html Annuario del Cobre. (1986-2005). COCHILCO.

Atacama Region. (2015). Retrieved June 24, 2015, from http://www.chileangovernment.cl/the-atacama-region

Auty, R. M., \& Mikesell, R. F. (1998). Sustainable Development in Minerals. New York: Oxford Press.

Banco Central de Chile. GDP by Region. (2015). (http://www.bcentral.cl/eng/index.asp), New Statistics Database: (http://www.bcentral.cl/eng/bde/index.htm), Access

Database: (http://si3.bcentral.cl/Siete/secure/cuadros/home.aspx?Idioma=en-US), Macro-Economic Statistics: (http://si3.bcentral.cl/Siete/secure/cuadros/arboles.aspx), Region III, (in search box): (http://si3.bcentral.cl/Siete/secure/common/Buscador_Series.aspx?buscar=Region\%20III). Retrieved July 8, 2015.

Dashwood, H. S. (2012). The Rise of Global Corporate Social Responsibility Mining and the Spread of Global Norms. Cambridge: Cambridge University Press.

Extractive Industries Transparency Initiative - EITI. (2015). Retrieved June 24, 2015, from https:/eiti.org/

Gerardu, J., \& Wasserman, C. (Editors). (1998). Summary of United States Environment Protection Agency's. November 16-20 - Fifth International Conference on Environmental Compliance and Enforcement. (Monterey, California). National Service Center for Environmental Publications. Retrieved June 24, 2015 from http://www.inece.org/5thvol2/5e.pdf

International Finance Corporation. (2006). Environmental, Health and Safety General Guidelines for Mining. 2006. Retrieved June 24, 2015, from http://www1.ifc.org/wps/wcm/connect/Topics_Ext_Content/IFC_ External_Corporate_Site/IFC+Sustainability/Sustainability+Framework/Environmental $\% 2 \mathrm{C}+\mathrm{Health} \% 2 \mathrm{C}+\overline{\mathrm{a}}$ nd+Safety+Guidelines/

Kellenberg, J. (1996). Accounting for Natural Resources in Ecuador: Contrasting Methodologies, Conflicting results. Environment Department Working Papers; no. 41. Environmental Economics Series. Washington, DC: World Bank. 
Lesser, J. A., Dodds, D. E., \& Zerbe Jr, R. O. (1997). Environmental Economics and Policy. Boston: Addison-Wesley.

Liebenthal, A., Michelitsch, R., \& Tarazona, E. (2005). Extractive Industries and Sustainable Development - An Evaluation of World Bank Group Experience. Washington, D. C.: World Bank.

Neumayer, E. (2000). Resource Accounting in Measures of Unsustainability - Challenging the World Bank's Conclusions. Environmental Resource Economics, 15, 257-278. http://dx.doi.org/10.1023/A:1008304812545

OECD. (2004). Measuring Sustainable Development: Integrated Economic, Environmental and Social Frameworks. Retrieved June 25, 2015, from http://www.oecd.org/site/worldforum/33703829.pdf

OECD. (2005). Environmental Performance Reviews - CHILE - Conclusions and Recommendations. Retrieved June 24, 2015, from http://www.oecd.org/env/country-reviews/34856244.pdf

Repetto, W. (1992). Accounting for environmental assets. Scientific American, 266(6), 64-70. In W. Magrath, M. Wells, C. Beer, \& F. Rossini (1989), Wasting Assets, Natural Resources in the National Income Accounts. Washington, DC.: World Resources Institute.

Resource Strategies Incorporated (RSI). (1990). Methodology to Measure the Economic Impact of Copper Mining and Mineral Processing Waste Regulations. Prepared for Bureau of Mines, Branch of Procurement. Washington, D.C. Final Report - May.

Schneider, J., Campbell, D., Vargo, C., \& Hall, R. (2011). An Analysis of reported Sustainability-Related Efforts in the Petroleum Refinery industry. Journal of Corporate Citizenship, 44, 69-84. http://dx.doi.org/10.9774/ GLEAF.4700.2011.wi.00006

Sernagomin - Servicio Nacional de Geologia y Mineria. (2005). Anuario de la Mineria de Chile. Retrieved July 8 , 2015, from http://biblioserver.sernageomin.cl/opac/DataFiles/anuario_2005.pdf

Thiele, L. P. (2013). Sustainability. New York: Hoboken - Wiley.

United Nations Department of Economic and Social Affairs - Division for Sustainable Development. (2008). Retrieved June 23, 2015, from http://www.un.org/esa/sustdev/index.html

United Nations Economic Commission for Europe. (2015). Retrieved April 2, 2015 http://www.unece.org/oes/ nutshell/2004-2005/focus_sustainable_development.html

United Nations Environmental Programme (UNEP). (2003). Implementation of Policy Response Packages to Promote Sustainable Management of Natural Resources - Confronting Sustainability in the Mining Sector Role for a Sustainability Fund. New York: United Nations.

Warhurst, A. (1994). Environmental Degradation from Mining And Mineral Processing In Developing Countries: Corporate Responses And National Policy. Paris, France: OECD.

World Bank Environment. (1995). Health and Safety Guidelines, Mining and Milling - Open Pit. Retrieved June 24, 2015, from http://commdev.org/files/821_file_WB_EHSGuideUG.pdf

World Commission on Environment and Development (WECD). (1987). Our Common Future. Oxford: Oxford University Press.

\section{Copyrights}

Copyright for this article is retained by the author(s), with first publication rights granted to the journal.

This is an open-access article distributed under the terms and conditions of the Creative Commons Attribution license (http://creativecommons.org/licenses/by/3.0/). 